\title{
Community of Aquatic Macroinvertebrates in an Atlantic Forest Stream, Brazil
}

\author{
Rafael Santos de Azevedo ${ }^{\text {, Leandro Dumas }}{ }^{2}$, Daniela Rodrigues ${ }^{1}$, Carla Ferreira Rezende ${ }^{\circledR}$, \\ Érica Pellegrini Caramaschi², Rosana Mazzoni ${ }^{4}$ \& Jorge Nessimian²
}

1. Universidade Federal de Juiz de Fora, e-mail: rafaelribio@gmail.com, danitarodrigues@gmail.com. 2. Universidade Federal do Rio de Janeiro, e-mail: dumas bioufrj@yahoo.com.br. erica.caramaschi@gmail.com. 3. Universidade Federal do Ceará, e-mail: carla.rezende@ufc.br (Autor para correspondência $^{\bowtie}$ ). 4. Universidade do Estado do Rio de Janeiro, e-mail: mazzoni@uerj.br.

\section{EntomoBrasilis 5 (3): 179-184(2012)}

\begin{abstract}
Composition, diversity and density of benthic macroinvertebrates were described based on samples from the four different sites of Rio Mato Grosso, Saquarema, Rio de Janeiro. Biotic and environmental data were obtained in January 2006 in microhabitats with different substrates. A total of 5.605 specimens of the 28 insect families and two crustaceous families are sampled. The lowest values of richness, diversity, equitability and density were observed in low altitude sites. The highest diversity and density values were observed in litter substrate, while sand substrate showed lower values of these parameters.
\end{abstract}

Keywords: Benthic macroinvertebrates; Coastal stream; Distribution; Taxonomic richness.

\section{Estrutura da Comunidade de Macroinvertebrados Aquáticos de um Riacho de Mata Atlântica, Brasil}

Resumo. A composição, diversidade e densidade de macroinvertebrados bentônicos foram descritas a partir de amostras provenientes de quatro localidades distintas do Rio Mato Grosso, Saquarema, Rio de Janeiro. Os dados bióticos e abióticos foram obtidos em janeiro 2006 em microhabitats com diferentes tipos de substrato. Foi amostrado um total de 5.605 espécimes de 28 famílias de insetos e duas de crustáceos. Os menores valores de riqueza, diversidade, equitabilidade e densidade foram registrados nas localidades de menor altitude. Folhiço foi o substrato com maiores valores de diversidade e densidade, enquanto areia apresentou os menores valores desses parâmetros.

Palavras-chave: Distribuição; Macroinvertebrados bentônicos; Riacho costeiro; Riqueza taxonômica.

A traditional approach to study of the stream organization is based on the concept of "River Continuum" proposed by VANNOTE et al. (1980), suggesting that physical characteristics are modified longitudinally from the headwaters to the mouth, forming a continuous gradient where the biotic communities are distributed. Currently, this concept is largely criticized by new theories about river ecology (WARD et al. 2002). Nevertheless, it is still explaining some patterns associated with the distribution of functional groups, especially in small lotic systems (e.g. WARD et al. 2002), where longitudinal links are stronger than the transversal ones.

Among the aquatic macroinvertebrates of lotic systems, insects are the most diverse and abundant ones (Hynes 1970; Bueno et al. 2003; KiKUCHI \& UIEDA 2005; RibEIRo \& UIEDA 2005). They are distributed throughout many available microhabitats. It mainly occurs due to their great diversity of forms and morphological adaptations (AlLAN 1995; HAUER \& RESH 1996; BAPTISTA et al. 2001) as well as the interaction between specific habit and physical habitat (VANnote et al. 1980; Resh \& Rosenberg 1984).

Water velocity, temperature and dissolved oxygen are the main abiotic variables of lotic systems (Allan 1995; КікUCHI \& UIEDA 1998), being responsible for the organization of the macroinvertebrate communities (BRANCO \& NECCHI JR. 1997; Gonçalves \& Aranha 2004). Nevertheless, the substrata (sand, gravel, rock or vegetation) are also important factors, since they can provide shelter against predation and food resource (SANSEVERINo et al. 1998; KiKUCHI \& UIEDA 2005).
The importance of macroinvertebrates to the ecological functioning of rivers is explained, among others, for their role in food chains. They act as a link between basal resources (algae and detritus) and fish (Allan 1995; HaUer \& Resh 1996; CARvalho \& UIEDA 2004), and they present species acting in several trophic levels. These characteristics allied to high taxonomic diversity (number of species) and high difference of susceptibility to environmental impacts allow us to use as bioindicators in assessing the biotic integrity of aquatic ecosystems

In this study we aimed to make a description of the macroinvertebrate structure community of Rio Mato Grosso, comparing four sites with different abiotic characteristics. We based our analysis on metrics such as macroinvertabrate density, composition, richness and diversity.

\section{MATERIAL AND METHODS}

Study Area. The Rio Mato Grosso sub-basin $\left(22^{\circ} 55^{\prime} \mathrm{S}, 42^{\circ} 35^{\prime} \mathrm{W}\right)$ has a drainage area of approximately $215 \mathrm{~km}^{2}$ and is located within Saquarema basin (Figure 1).

The area is delimitated by extensive highlands areas of Serra do Mar mountain range (Serras do Mato Grosso, Redonda, do Tingui, Portelas, Amar e Querer, da Boa Esperança, Castelhana e do Palmital) (Borges 2009).

Rio Mato Grosso drains the northwestern portion of Saquarema municipality. The stream main source is situated in the Serra do Mato Grosso (about 800 a.s.l.), dewatering in Saquarema lagunar 
system as a $4^{\text {th }}$ order stream, with a planimetric area of $30 \mathrm{~km}^{2}$ There are two main geomorphological compartments: 1) Mato Grosso plateau, situated in the stream high course and formed by Precambrian crystalline rocks, and 2) Rio Mato Grosso lowland, an extensive area formed by quaternary fine-grained sediments (sand, mud and clay) derived from river terrace and shoreline (BORgES 2009).

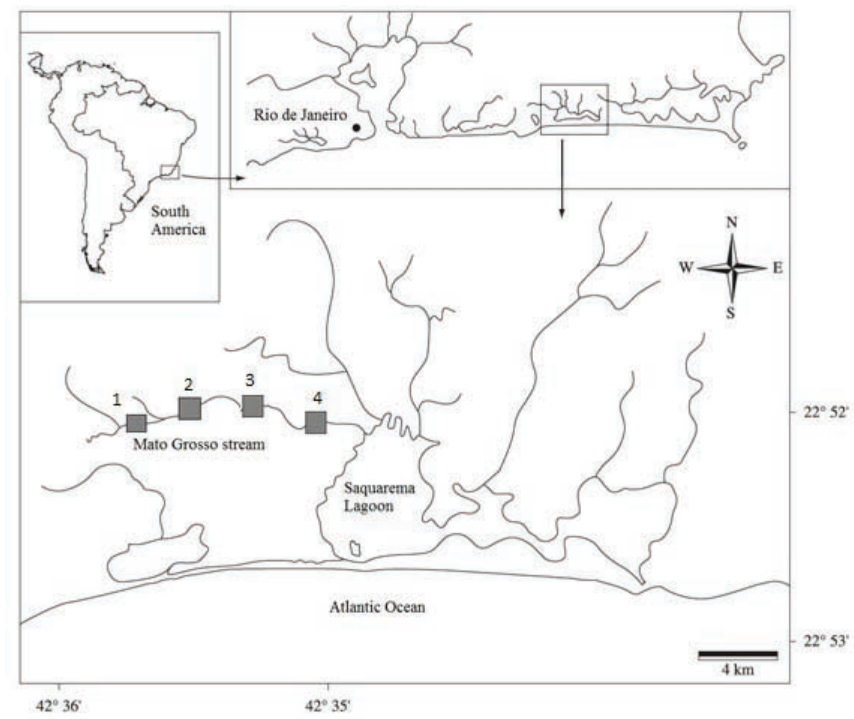

Figure 1. Map from Rio Mato Grosso, highlighting the collecting localities.

The climate is typical tropical hot and humid, with wet summer. In all seasons of the year, the temperature is high, with low temperature range (about $5^{\circ} \mathrm{C}$ ). Annual rainfall varies between 750 and $1250 \mathrm{~mm}$, concentrated during the months of October throught March (ANDRÉ et al. 2009).

Atlantic Rain Forest can be founded in the plateau of Serra do Mato Grosso, although huge portion was damaged due to deforestation and other human activities, being replaced by pasture lands and young secondary forest. In lowlands of Mato Grosso river the vegetation is typical of Restinga, with small trees, shrubs and herbaceous plant. Mangroves and ponds are found near Lagoa de Saquarema (BorgEs 2009).

Sampling. One single sampling episode was performed during January 2006. Four sites with different degrees of conservation were sampled through the river; along a gradient upstream to downstream. Sites 1, 2 and 3 are covered by riparian vegetation, forming a closed canopy. The river substrate is composed mainly by sand, gravel and rocks. Site 4 is located in an urban area, without canopy formation, and with substrate composed mainly by sand, gravel and few cobles. In order to assess the structural variation, a transect was made at every five meters. The following environmental parameters were measured at each transect: current velocity $(\mathrm{m} / \mathrm{s}$, measured by digital flowmeter - Global Water FP 1010), stream depth and width (cm, measured with a graduate ruler/tape)

In addition, at each study site were registered altitude (m), length of sampling site $(\mathrm{m})$, conductivity $(\mu \mathrm{s})$ and turbidity (categorized). Three samples of each substratum type (rock, sand, and leaf litter) were collected with a Surber net sampler $\left(0.09 \mathrm{~m}^{2}\right.$ sampling area, $180 \mu \mathrm{m}$ mesh net), totalizing 36 samples. Each sample was wrapped in a plastic bag and fixed in $80 \%$ ethanol. In the laboratory, samples were sieved (mesh $180 \mu \mathrm{m}$ ), washed under running water and then screened. Macroinvertebrates were separated from the substrate and identified to family level using identification keys and taxonomic descriptions (LEHMKUHL 1979; Merrit \& Cummins 1996; Nieser \& Mello 1997; Carvalho \& CAlil 2000; Da Silva et al. 2003; Mello 2003; Olifiers et al. 2004; Pes et al. 2005; CALOR 2007; PAssos et al. 2007).

Data analysis. For each site and substratum sample we considered: composition by family, macroinvertebrate densities (ind $/ \mathrm{m}^{2}$ ), Shannon diversity $(\mathrm{H})$ and Shannon evenness $(\mathrm{J})$ (MAGURRAn 2005). Shannon diversity measures the "uncertainty" of a taxon selected at random from the community. High diversity is associated with high uncertainty and low diversity with low uncertainty (TziLKowski et al. 2009). Shannon eveness is the ratio of the observed Shannon diversity to the maximum possible diversity, that is, diversity when individuals are distributed as evenly as possible among the species (TziLkowski et al. 2009). Rarefaction analysis was applied in order to standardize the relationship between number of sampled individuals and species richness of each sampling site (KREBS 1989). Student t test was carried out to verify differences between site and substrate diversities (ZAR 1999).

\section{RESULTS}

Among all the physical variables, turbidity was the one with highest variation, but higher altitude sites were the ones with lower water turbidity. The other variables presented small variation among sites. The smallest variation of physical parameters was found in sites 1 and 2 (Table 1 ).

A total of 5.605 individuals were collected, distributed in nine orders, 28 insect families and two crustaceous families. The most abundant families were: Chironomidae (50.70\% of total density), Simuliidae (27.03\%), and Baetidae (5.41\%) (Table 2).

A decrease in richness, diversity and equitability, was registered in the benthic macroinvertebrate community from low altitude sites. Density values followed the same spatial pattern, decreasing from sites in the upper stretch to sites in the intermediary stretch; however, the highest density value was obtained in site 2 because one of the substrates sampled presented a greater abundance of Simuliidae (Table 3).

Table 1. Physical characterization of the different sampling sites in the Rio Mato Grosso, Saquarema, RJ.

\begin{tabular}{|c|c|c|c|c|c|c|c|c|c|c|c|}
\hline \multirow[b]{2}{*}{$\stackrel{\text { Dै }}{=}$} & \multirow{2}{*}{ 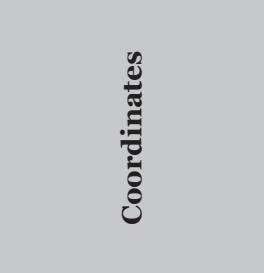 } & \multirow{2}{*}{ 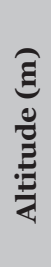 } & \multirow{2}{*}{ 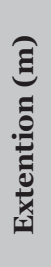 } & \multicolumn{2}{|c|}{ Width (m) } & \multicolumn{2}{|c|}{ Depth (m) } & \multicolumn{2}{|c|}{ Velocity $(\mathrm{m} / \mathrm{s})$} & \multirow{2}{*}{$\underset{E}{\stackrel{E}{E}}$} & \multirow{2}{*}{ 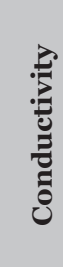 } \\
\hline & & & & 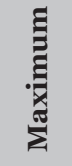 & 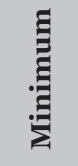 & 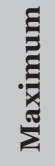 & 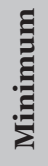 & 胥 & 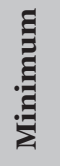 & & \\
\hline 1 & $22^{\circ} 53^{\prime}$ 'S $42^{\circ} 39^{\prime} \mathrm{W}$ & 90 & 40 & $5 \cdot 4$ & 1.53 & 26 & o & 1.02 & o & low & 69.4 \\
\hline 2 & $22^{\circ} 53^{\prime} \mathrm{S} 42^{\circ} 39^{\prime} \mathrm{W}$ & 44 & 45 & 5 & 1.25 & 36 & o & 0.84 & o & low & 59 \\
\hline 3 & $22^{\circ} 53^{\prime} \mathrm{S} 42^{\circ} 38^{\prime} \mathrm{W}$ & 40 & 45 & $5 \cdot 72$ & $3 \cdot 35$ & 34 & 2 & 0.82 & o & mean & $73 \cdot 7$ \\
\hline 4 & $22^{\circ} 52^{\prime} \mathrm{S} 42^{\circ} 37^{\prime} \mathrm{W}$ & 40 & 50 & 6.3 & 4.2 & 42 & o & 0.75 & o & mean & 80.3 \\
\hline
\end{tabular}


Rarefaction analysis demonstrated a decrease in variance in accordance with the increase of the number of individuals for all sites, indicating sampling efficiency. Thus, a decreasing pattern of species richness was observed between the studied sites along Rio Mato Grosso (Figure 2).

Considering the substrate analysis, litter presented a higher diversity, as well as a higher density of individuals in most locations except for location 2, where the substrate and sand showed greater diversity.

\section{DISCUSSION}

Patterns of macroinvertebrate diversity along Rio Mato Grosso can be related to the preservation degree of the stream. BuENo et al. (2003), when comparing two streams in Atlantic Forest, observed that best preserved streams presented a greater proportion of stable substrate (litter and rocks). These substrates, besides being less vulnerable to physical variations such as current velocity, provide a greater number of shelters and food availability to macroinvertebrates (RESH \& ROSENBERG 1984; ALLAN

Table 2. Total density and percentage (in brackets) of the benthic macro invertebrate families collected in the Mato Grosso River, Saquarema, RJ.

\begin{tabular}{|c|c|c|c|c|}
\hline CLASS INSECTA & Locality 1 & Locality 2 & Locality 3 & Locality 4 \\
\hline \multicolumn{5}{|c|}{ COLEOPTERA } \\
\hline Dryopidae & $1.23(0.06)$ & & & \\
\hline Elmidae & $188.89(\mathbf{8 . 6 6})$ & $132.09(\mathbf{5 . 3 3})$ & $45.67(\mathbf{3 . 2 3})$ & $41.66(3.75)$ \\
\hline Hydraenidae & $1.23(\mathbf{0 . 0 6})$ & & & \\
\hline \multicolumn{5}{|c|}{ DIPTERA } \\
\hline Nematocera não ident. & $1.23(0.06)$ & & & \\
\hline Ceratopogonidae & & $1.23(\mathbf{0 . 0 5})$ & & \\
\hline Chironomidae & $837.04(\mathbf{3 8 . 4 0})$ & $746.91(\mathbf{3 0 . 1 4})$ & $1004.92(71.02)$ & $918.04(\mathbf{8 2 . 7 3})$ \\
\hline Simuliidae & 574.07 (26.33) & $1371.60(\mathbf{5 5 \cdot 3 5})$ & $13.58(\mathbf{0 . 9 6 )}$ & $2.77(\mathbf{0 . 2 5})$ \\
\hline Tipulidae & $1.23(\mathbf{0 . 0 6})$ & & & \\
\hline Empididae & $12.35(\mathbf{0 . 5 7 )}$ & $7.40(\mathbf{0 . 3 0})$ & & \\
\hline Phoridae & $1.23(\mathbf{0 . 0 6})$ & $1.23(\mathbf{0 . 0 5})$ & & \\
\hline \multicolumn{5}{|c|}{ EPHEMEROPTERA } \\
\hline Baetidae & $33.33(\mathbf{1 . 5 3})$ & $32.09(\mathbf{1 . 3 0})$ & $219.75(15 \cdot 53)$ & $61.11(5 \cdot 51)$ \\
\hline Leptohyphidae & $48.15(\mathbf{2 . 2 1})$ & 49.32 (1.99) & $4.93(\mathbf{0 . 3 5})$ & \\
\hline Leptophlebiidae & $80.25(\mathbf{3 . 6 8})$ & $51.85(\mathbf{2 . 0 9})$ & $123.45(\mathbf{8 . 7 2})$ & $44.44(4.01)$ \\
\hline \multicolumn{5}{|c|}{ HEMIPTERA } \\
\hline Gerridae & & $7.40(\mathbf{0 . 3 0})$ & & \\
\hline Veliidae & $1.26(5 \cdot 78)$ & $2.47(\mathbf{0 . 1 0})$ & $1.23(\mathbf{0 . 0 9})$ & \\
\hline \multicolumn{5}{|c|}{ LEPIDOPTERA } \\
\hline Pyralidae & $3.70(\mathbf{0 . 1 7})$ & $2.47(\mathbf{0 . 1 0})$ & $1.23(\mathbf{0 . 0 9})$ & \\
\hline \multicolumn{5}{|c|}{ ODONATA } \\
\hline Calopterygidae & $11.11(\mathbf{0 . 5 1})$ & & $12.34(\mathbf{0 . 8 7})$ & $1.38(\mathbf{0 . 1 3})$ \\
\hline Megapodagrionidae & $2.47(\mathbf{0 . 1 1})$ & & $3.70(\mathbf{0 . 2 6})$ & \\
\hline Gomphidae & $3.70(\mathbf{0 . 1 7})$ & $7.40(\mathbf{0 . 3 0})$ & & \\
\hline Libellulidae & & $8.64(\mathbf{0 . 3 5})$ & $3.70(\mathbf{0 . 2 6})$ & \\
\hline \multicolumn{5}{|c|}{ PLECOPTERA } \\
\hline Grypopterigidae & $8.64(\mathbf{0 . 4 0})$ & $2.47(\mathbf{0 . 1 0})$ & & \\
\hline Perlidae & $3.70(\mathbf{0 . 1 7})$ & & & \\
\hline \multicolumn{5}{|c|}{ TRICHOPTERA } \\
\hline Anomalopsychidae & $4.94(\mathbf{0 . 2 3})$ & & & \\
\hline Calamoceratidae & $2.47(\mathbf{0 . 1 1})$ & & & \\
\hline Hydroptilidae & $9.88(\mathbf{0 . 4 5})$ & $7.40(\mathbf{0 . 3 0})$ & $9.87(\mathbf{0 . 7 0})$ & \\
\hline Hydropsychidae & $214.81(9.85)$ & $32.10(\mathbf{1 . 3 0})$ & $6.17(\mathbf{0 . 4 4})$ & $22.22(2.00)$ \\
\hline Leptoceridae & $1.23(\mathbf{0 . 0 6})$ & $2.47(\mathbf{0 . 1 0})$ & & \\
\hline Philopotamidae & $11.11(0.51)$ & $9.89(\mathbf{0 . 4 0})$ & & \\
\hline
\end{tabular}

\section{CLASS MALACOSTRACA}

\section{DECAPODA}

\section{Trichodactylidae}

Trichodactylus fluviatilis

\section{Palaemonidae}

Macrobrachium potiuna 
Table 3. Individuals density, diversity (Shannon) and equitability index of the sampling sites of Mato Grosso River, Saquarema, RJ.

\begin{tabular}{ccccc}
\hline Locality & Richness & Density & Shannon & Equitability J \\
\hline 1 & 26 & 2183.95 & 1.90 & 0.58 \\
2 & 20 & 2477.78 & 1.26 & 0.42 \\
3 & 14 & 1450.82 & 1.12 & 0.42 \\
4 & 12 & 1109.72 & 0.90 & 0.36 \\
\hline
\end{tabular}
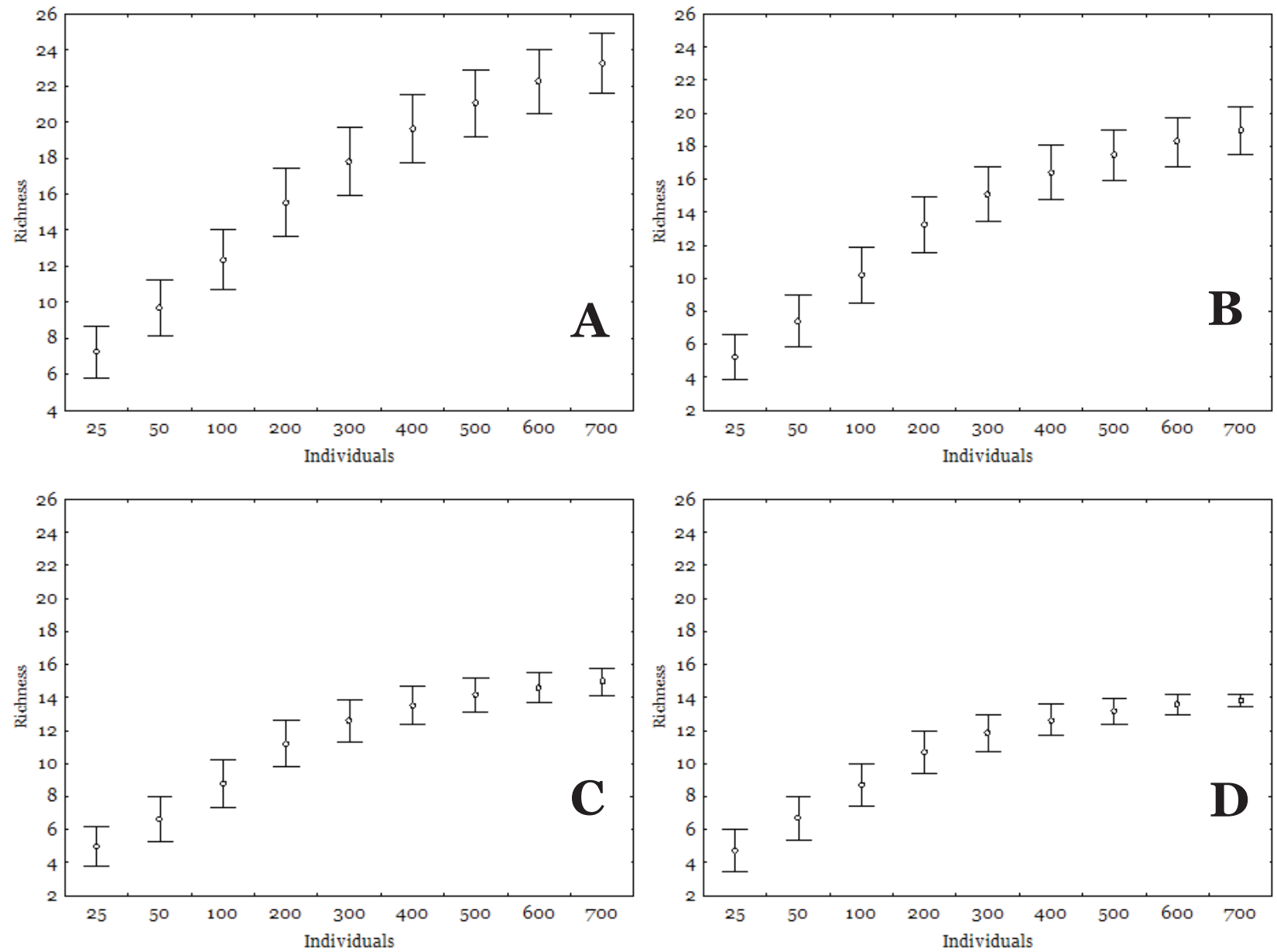

Figure 2. Rarefaction data (expected richness of species and variance) for sampling sites of Rio Mato Grosso, Saquarema $-\mathrm{RJ}$. Where $\mathrm{A}=\mathrm{Site} 1, \mathrm{~B}=$ site $2, \mathrm{C}=$ site 3 and $\mathrm{D}=$ site 4 .

Table 4. Richness, density of individuals, diversity index and Shannon equitability, calculated according to substrates (sand, litter and rocky) of the Rio Mato Grosso, Saquarema, RJ.

\begin{tabular}{|c|c|c|c|c|}
\hline & Richness & Density & Shannon & Equitability J \\
\hline \multicolumn{5}{|c|}{ Locality 1} \\
\hline Sand & 10 & 351.85 & 1.50 & 0.65 \\
\hline Litter & 21 & 4425.93 & 2.23 & 0.73 \\
\hline Stone & 15 & 1392.59 & 2.13 & 0.78 \\
\hline \multicolumn{5}{|c|}{ Locality 2} \\
\hline Sand & 9 & $118.5^{2}$ & 1.42 & 0.64 \\
\hline Litter & 17 & 4577.78 & 1.35 & 0.47 \\
\hline Stone & 11 & 376 & 1.47 & 0.61 \\
\hline \multicolumn{5}{|c|}{ Locality 3} \\
\hline Sand & 3 & 159.26 & 0.74 & 0.68 \\
\hline Litter & 13 & 3888.89 & 1.57 & 0.61 \\
\hline Stone & 5 & 300 & 1.34 & 0.83 \\
\hline \multicolumn{5}{|c|}{ Locality 4} \\
\hline Sand & 7 & 192.59 & 1.13 & 0.58 \\
\hline Litter & 7 & 2622.22 & 1.48 & 0.76 \\
\hline Stone & 5 & 92.59 & 0.76 & 0.47 \\
\hline
\end{tabular}


1995; KIKUCHI \& UIEDA 1998).

The high diversity found in localities one and two (upstream sites) can be associated to physical factors such as: preserved tree cover, moderate current, low depth and high levels of organic matter (BUENo et al. 2003; CARVAlHo \& UIEDA 2004). Localities three and four show low diversity; this result can be related to high depth, current and water turbidity. At the Mato Grosso stream, part of the physical alterations that occur in the lower portion can be attributed to anthropogenic actions caused by the transformation of the marginal area into pasture sites and by the removal of sand from the river bed.

Second-order stream stretches are associated to a high diversity of benthic macroinvertebrates (e.g. STOUT \& VANDERMEER 1975; VINSON \& HAWKINS 1998). However, according to BAPTISTA et al. (2001) the increase in the taxonomic resolution may change this diversity pattern. In agreement with the River Continuum Concept (VANNOTE et al. 1980), the medium river stretches ( $3^{\text {rd }}$ and $4^{\text {th }}$ orders) are the most diverse ones. This pattern was founded in Rio Macaé basin by BAPTISTA et al. (2001). On the other hand, this pattern was not founded in Rio Mato Grosso. The diversity values were lower in the less preserved sites. According to MatthaEI et al. (2006) and URBAN et al. (2006) there is a reduction in macroinvertebrate diversity in urban areas and/or in sites next to cattle and agricultural activities.

Reduction of the environmental structural heterogeneity is associated with quantity and quality of available substrate for macroinvertebrate colonization (ALLAN 1995). The nature of substrate can be a limiting factor when considering fauna composition and distribution (BuENo et al. 2003). Distribution of some groups such as Trichoptera and Coleoptera (Elmidae) can be related to the quality of organic substrate (HuAMANTINCO \& NESSIMIAN 1999; PASSOS et al. 2003). Litter and rock substrates were the ones with higher values of macroinvertebrate density and diversity, while sand substrate presented the lower ones, corroborating other studies conducted in Atlantic Forest streams (e.g. BAPTISTA et al. 2001; KIKUCHI \& UIEDA 2005).

According to SANSEVERINo et al. (1998) most aquatic insects can be found living in more than one substrate, with some insects demonstrating preference for certain types of substrates 2002). In the four localities sampled at the Mato Grosso river, the predominant taxon observed was Chironomidae, in both abundance and density, a result which was also observed by Gonçalves \& Aranha (2004); Ribeiro \& Uieda (2005) in other water bodies, reinforcing the great importance of these Diptera in benthonic community structure. We conclude that richness, diversity, equitability and density values of benthic macroinvertebrates of Rio Mato Grosso varied according to environmental changes, and also due to reduction of substrate availability such as litter and rocks.

\section{ACKNOWLEDGMENTS}

We thank our friends of Laboratório de Ecologia de Peixes, especially M. Moraes, L. R. Manna, V. T. Cardoso and J. C. Miranda for their assistance during fieldwork. The financial support individual grants of CFR (CNPq 140928/2005-7) EPC (CNPq 470587/2004-0) and RM (CNPq 311976 / 2004-O).

\section{REFERENCES}

Allan, J.D., 1995. Stream Ecology: Structure and function of running water. London, Chapman \& Hall, 388 p.

André, R.G.B., V.S. Marques, F.M.A. Pinheiro \& A.S. Ferraudo, 2009. Identificação de regiões pluviométricamente homogêneas no Estado do Rio de Janeiro, utilizando-se valores mensais. Revista Brasileira de Metereologia, 23: 501509 .
Baptista, D.F., L.F.M. Dorvillé, D.F. Buss \& J.L. Nessimian, 2001. Diversity and habitat preference of aquatic insects along the longitudinal gradient of the Macaé river basin, Rio de Janeiro, Brazil. Revista Brasileira de Biologia, 61: 249-258.

Borges, R., 2009. Caracterização sócio-ambiental e ordenamento territorial para a bacia do Rio Mato Grosso, Saquarema - RJ. Caminhos de Geografia, 10: 142-152.

Branco, L.H.Z. \& O. Necchi Jr., 1997. Variação longitudinal de parâmetros físicos e químicos em três rios pertencentes a diferentes bacias de drenagem na região noroeste do Estado de São Paulo. Acta Limnologica Brasiliensia, 9: 165-177.

Bueno, A.A.P., G.B. Buckup \& B.D.P. Ferreira, 2003. Estrutura da comunidade de invertebrados bentônicos em dois cursos d'água do Rio Grande do Sul, Brasil. Revista Brasileira de Zoologia, 20: 115-125.

Calor, A.R., 2007. Trichoptera. In: Froehlich, C. G. (Org.). Guia on-line de identificação de larvas de insetos aquáticos do Estado de São Paulo, accessible at http://sites.ffclrp.usp.br/aguadoce/trichoptera/index trico. htm (Accessed 11/05/2008).

Carvalho, A.L. \& E.R. Calil, 200o. Chaves de identificação para as famílias de Odonata (Insecta) ocorrentes no Brasil, adultos e larvas. Papéis Avulsos de Zoologia, 41: 223-241.

Carvalho, E.M. \& V.S. Uieda, 2004. Colonização por macroinvertebrados bentônicos em substrato artificial e natural em um ricaho da serra de Itatinga, São Paulo, Brasil. Revista Brasileira de Zoologia, 21: 287-293.

Da-Silva, E.R., F.F. Salles, J.L. Nessimian \& L.B.N. Coelho, 2003. A identificação das famílias de Ephemeroptera (Insecta) ocorrentes no Estado do Rio de Janeiro: chave pictórica para as ninfas. Boletim do Museu Nacional, Nova Série, Zoologia, 508: 1-6.

Gonçalves, F.B. \& J.M.R. Aranha, 2004. Ocupação espaçotemporal pelos macroinvertebrados bentônicos na bacia do rio Ribeirão, Paranaguá, PR (Brasil). Acta Biológica Paranaense, 33: 181-191.

Hauer, F.R. \& V.H. Resh, 1996. Benthic macroinvertebrates. p. 339-369. In: Hauer, F.R. \& G.A. Lamberti (Eds.). Methods in stream ecology. San Diego, California, Academic Press, Inc., $877 \mathrm{p}$.

Huamantinco, A.A. \& J.L. Nessimian, 1999. Estrutura e distribuição espacial da comunidade de larvas de Trichoptera (Insecta) em um tributário de primeira ordem do Rio Paquequer, Teresópolis, RJ. Acta Limnologica Brasiliensis, 11: 1-16.

Hynes, H.B.N., 1970. The ecology of running waters. Toronto, Ontario, Univ. of Toronto Press, 555 p.

Kikuchi, R.M. \& V.S. Uieda, 1998. Composição da comunidade de invertebrados de um ambiente lótico tropical e sua variação espacial e temporal. p. 157-173. In: Nessimian J.L. \& A.L. Carvalho (Eds.). Ecologia de Insetos Aquáticos. Series Oecologia Brasilienses. PPGE, UFRJ, Rio de Janeiro, 309 p.

Kikuchi, R.M. \& V.S. Uieda, 2005. Composição e distribuição dos macroinvertebrados em diferentes substratos de fundo de um riacho no município de Itatinga, São Paulo, Brasil. Entomologia y Vectores, 12: 193-231.

Krebs, C.J., 1989. Ecological Methodology. Harper Collins Publishers, New York, 654 p.

Lehmkuhl, D.M., 1979. How to know the aquatic insects. Dubuque, Iowa, Wm. C. Brown Co. Publishers, 168 p.

Magurran, A.E., 2005. Measuring Biological Diversity. United Kingdom, Blackwell Publishing, $256 \mathrm{p}$.

Matthaei, C.D., F. Weller, D.W. Kelly \& C.R. Townsend, 2006. Impacts of fine sediment addition to tussock, pasture, dairy and deer farming streams in New Zealand. Freshwater Biology, 51: 2154-2172.

Mello, G.A.S. 2003. Manual de identificação de Crustacea Decapoda de água doce do Brasil. São Paulo, Loyola, 429 p.

Merrit, R.W. \& K.W. Cummins, 1996. An introduction to the Aquatic Insects of North America. Kendall/Hunt Publishing Company, $862 \mathrm{p}$. 
Nieser, N. \& A.L. Melo, 1997. Os Heterópteros Aquáticos de Minas Gerais: Guia introdutório com chave de identificação para as espécies de Nepomorpha e Gerromorpha. Belo Horizonte, Editora UFMG, $180 \mathrm{p}$.

Olifiers, M.H, L.F.M. Dorvillé \& J.L. Nessimian, 2004. A key to Brazilian genera of Plecoptera (Insecta) based on nymphs. Zootaxa, 651: 1-15.

Passos, M.I.S, J.L. Nessimian \& L.F.M. Dorvillé, 2003. Distribuição espaço-temporal da comunidade de Elmidae (Coleoptera) em um rio na Floresta da Tijuca, Rio de Janeiro, RJ. Boletim Museu Nacional, 509: 1-9.

Passos, M.I.S, J.L. Nessimian \& N.F. Junior, 2007. Chaves para identificação dos gêneros de Elmidae (Coleoptera) ocorrentes no Estado do Rio de Janeiro, Brasil. Revista Brasileira de Entomologia, 51: 42-53.

Pes, A.M.O, N. Hamada \& J.L. Nessimian, 2005. Chaves de identificação de larvas para famílias e gêneros de Trichoptera (Insecta) da Amazônia Central, Brasil. Revista Brasileira de Entomologia, 49: 181-204.

Resh, V.H. \& D.M. Rosenberg, 1984. The Ecology of Aquatic Insects. New York, Praeger Publishers, 625 p.

Ribeiro, L.O. \& V.S. Uieda, 2005. Estrutura da comunidade de macroinvertebrados bentônicos de um riacho de serra em Itatinga, São Paulo, Brasil. Revista Brasileira de Zoologia, 22: 613-618.

Sanseverino, A.M., J.L. Nessimian \& A.L.H. Oliveira, 1998. A fauna de Chironomidae (Diptera) Em diferentes biótopos aquáticos na Serra do Subaio (Teresópolis, RJ). p. 253-263. In: Nessimian, J.L. \& A.L. Carvalho (Eds). Ecologia de Insetos Aquáticos. Series Oecologia Brasiliensis, vol. V. PPGE-UFRJ, Rio de Janeiro, Brasil.
Stout, J. \& J. Vandermeer, 1975. Comparison of species richness for Stream-Inhabiting insects in tropical and mid latitude streams. American Naturalist, 967: 263-280.

Tzilkowski, C.J., K.K. Callahan, M.R. Marshall \& A.S. Weber, 2009. Integrity of benthic macroinvertebrate communities in Delaware Water Gap National Recreation Area: Eastern Rivers and Mountains Network 2008 summary report. Natural Resource Data Series NPS/ERMN/NRDS-2009, National Park Service, Fort Collins, CO, 17 p.

Urban, M.C., D.K. Skelly, D. Burchsted, W. Price \& S. Lowry, 2006. Strean communities across a rural-urban landscape gradient. Diversity \& Distributions, 12: 337-350.

Vannote, R.L., G.W. Minshall, K.W. Cummins, J.R. Sedell \& C.E. Cushing, 1980. The river continuum concept. Canadian Journal of Fisheries and Aquatic Sciences, 37: 130-137.

Vinson, M.R. \& C.P. Hawkins, 1998. Biodiversity of stream insects: variation at local, basin, and regional scales. Annual Review of Entomology, 43: 271-293.

Ward, J.V., K. Tockner, D.B. Arscott \& C. Claret, 2002. Reverine landscape diversity. Freshwater Biology, 47: 517-539.

Zar, J.H., 1999. Biostatistical Analysis. New Jersey, PrenticeHall, 663 p.

\section{Recebido em: 26/06/2011} Aceito em: 19/o8/2012 $* * * * * * * * * *$

Como citar este artigo:

Azevedo, R.S., L. Dumas, D. Rodrigues, C.F. Rezende, É.P. Caramaschi, R. Mazzoni \& J. Nessimian, 2012. Community of Aquatic Macroinvertebrates in an Atlantic Forest Stream, Brazil. EntomoBrasilis, 5(3): 179-184.

Acessível em: http://www.periodico.ebras.bio.br/ojs/index.php/ebras/article/view/169
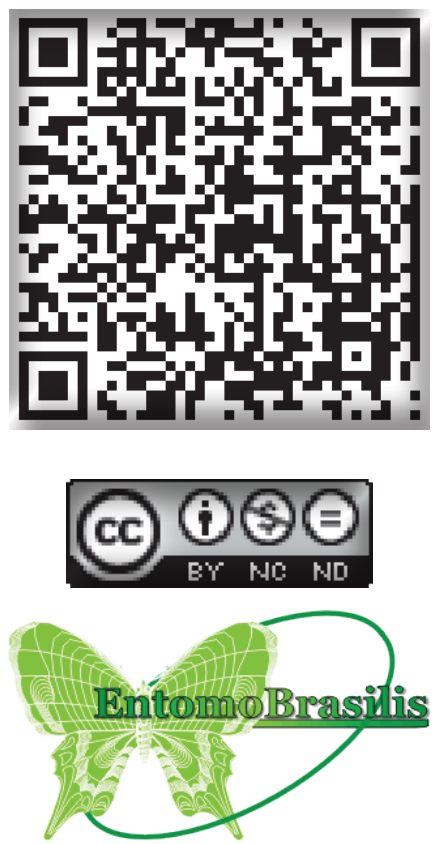